\title{
Industrialisasi Dan Berkembangnya Kota Malang Pada Awal Abad Ke-20
}

\section{Winin Maulidya Saffanah}

Program Studi Pendidikan Sejarah dan Sosiologi, Fakultas Pendidikan Ilmu Sosial dan Humaniora, IKIP Budi Utomo Malang

Abstrak

Kehadiran Kota Malang sebagai Kotapraja pada tahun 1914 tidak dapat dilepaskan dari industrialisasi yang terjadi di kota tersebut pada awal abad ke-20. Kehadiran dua pabrik gula yaitu Kebon Agung dan Krebet Baru pada dekade 1900-an telah mendorong pertumbuhan Kota Malang dengan infrastruktur yang cukup memadai dan penduduk yang cukup padat. Pada dekade 1930-an, industri gula ini diganti dengan industri rokok sebagai salah satu penopang perkembangan kota Malang. Salah satu penyebab dari berdirinya pabrik-pabrik ini adalah diterbitkannya Undang-undang Gula dan Undang-undang Agraria pada tahun 1870. Kedua undang-undang ini menyebabkan wilayah Malang yang berada di dekat gunung dan cukup subur dibanjiri oleh modal swasta yang mendirikan berbagai perkebunan. Wilayah yang kelak menjadi Kota Malang sendiri merupakan titik pengumpulan yang juga ditinggali oleh banyak pemilik perekebunan sehingga akhirnya dibentuk infrastruktur yang memadai. Diresmikannya Kota Malang pada 1914 sendiri sangat terpengaruh dengan berdirinya banyak perkebunan dan industrialisasi ini. Kebutuhan akan infrastruktur yang memadai serta transportasi yang lancar membuat Kota Malang akhirnya berkembang sangat pesat dan memiliki segala fasilitas pendukung yang memadai. Seiring berjalannya waktu, industri ini tetap menjadi salah satu tulang punggung yang mendorong perekembangan Kota Malang.

Kata Kunci: Industrialisasi, Kota Malang, Perkebunan

\section{Pendahuluan}

Kota Malang merupakan salah satu daerah yang lahir berkat industrialisasi yang massal terjadi pada akhir abad ke-19 hingga awal abad ke-20. Status kotamadya sendiri didapat oleh Malang pada tahun 1914 setelah sebelumnya hanya menjadi bagian dari Karesidenan Pasuruan. Awal abad ke-20 ini sendiri juga menandai mulai berkembangnya wilayah Hindia Belanda setelah Ratu Wilhemina yang baru menjabat bertekad melakukan politik balas budi atau biasa disebut politik etis.

Tiga fokus besar dari politik etis ini adalah pada irigasi, pendidikan, dan migrasi (Budiono, 2016: 56). Secara efektif, program ini dimulai pada tahun 1901, masih berjalan hingga sekitar 1920-an dan akhirnya dihentikan pada 1930-an setelah dana yang disediakan semakin mengecil. Dua program yang paling berdampak terhadap kota Malang pada masa politik etis ini adalah irigasi dan pendidikan.

Pembangunan sisterm irigasi modern telah membuat wilayah malang dikelilingi banyak pertanian dan perkebunan seperti teh, kopi, tembakau dan gula yang mendorong terbentuknya industri di wilayah ini. Dalam bidang pendidikan sendiri, Malang memiliki sejumlah sekolah modern yang bermutu dan melahirkan tenaga kerja yang sangat dibutuhkan oleh industri ini. Hal lain yang menjadi titik tolak 
industrialisasi di Malang adalah UU Agraria dan UU Gula pada tahun 1870. Industri gula ini adalah salah satu yang paling awal muncul di Malang dengan berdirinya Pabrik Gula Kebon Agung pada 1905 dan Pabrik Gula Krebet pada 1906. Tanah di wilayah Malang yang subur telah menarik minat berbagai pengusaha untuk menanam karet, kopi, teh, dan terutama tebu. Menarik dicermati bagaimana Malang yang sebelumnya hanya merupakan salah satu bagian Karesidenan Pasuruan kemudian bertumbuh besar dan sangat pesat masa itu. Hal ini bahkan menjadi fondasi bagi berkembangnya Kota Malang saat ini sebagai kota terbesar kedua di Jawa Timur.

Walau saat ini Malang dibedakan menjadi tiga daerah yaitu Kota Malang, Kabupaten Malang, dan Kota Batu, namun dalam penelitian ini sebutan Malang digunakan secara luas untuk ketiga daerah tersebut. Hal ini mengingat pada masa Hindia Belanda serta sebelumnya, wilayah Malang mencakup daerah yang sangat luas tersebut. Berbagai modal baik dari sumber daya alam maupun sumber daya manusia yang dimaksimalkan telah melahirkan Malang sebagai kota yang besar berkat industrialisasi tersebut. Penelitian ini ingin menyoroti peran terjadinya industrialisasi ini dalam kelahiran Kota Malang.

\section{Sejarah Lahirnya Kotapradja Malang}

Malang sebagai Kotapradja atau Stadsgemeente sendiri lahir pada masa pemerintah kolonial Hindia Belanda pada tahun 1914. Walau begitu, Malang sebagai sebuah daerah sudah memiliki usia yang jauh lebih tua yaitu sejak tahun 760 yang ditandai dengan prasasti Dinoyo yang mewartakan mengenai kerajaan Kanjuruhan yang bertahta di wilayah Malang pada masa itu.

Dalam rentang waktu antara tahun 760 sebagai tahun yang dianggap kelahiran Kabupaten Malang hingga 1914 ketika Kotapradja Malang terbentuk, terdapat sejarah yang cukup banyak di wilayah tersebut. Malang merupakan tempat lahir, terbentuk, dan tumpasnya salah satu kerajaan besar di Nusantara yaitu kerajaan Singosari yang kemudian menurunkan imperium selanjutnya, kerajaan Majapahit. Pada masa sesudahnya, wilayah Malang juga dikenal sebagai benteng kuat yang mampu menahan invasi Mataram ke wilayah Jawa Timur.

Handinoto \& Soehargo (1996: 15) mengutip dari buku Kotapraja Malang 50 Tahun menyebut bahwa wilayah Kota Malang sebagai pusat kerajaan sendiri sudah ada pada tahun 1400. Letak pusat kerejaan ini berada di tikungan Sungai Brantas dan kemudian dibangun sebuah benteng kokoh yang diberi nama Kutobedah. Belanda mulai menguasai Malang pada tahun 1767. Pada saat itu, mereka langsung mendirikan benteng untuk memperkuat kedudukan dan kemudian dibangun pemukiman Belanda di dalamnya. Benteng 
ini sendiri didirikan di wilayah yang kini ditempati oleh Rumah Sakit Syaiful Anwar. Pada era kolonial, wilayah Malang juga merupakan salah satu basis pertahanan bagi masyarakat sebelum akhirnya berhasil dikuasai. Malang kemudian menjadi salah satu kota militer yang cukup kuat dan akhirnya terus berkembang dengan industrialisasi gula dan berdirinya banyak sekolah modern.

Basundoro (2005: 274) menyebut bahwa pada awal masuknya kekuasaan kolonial Belanda ke Malang, mereka tidak mengubah kota itu secara besar dan tetap memposisikannya sebagai kota pedalaman dengan segala fungsinya. Lokasi Malang yang cukup tinggi dan dikelilingi pegunungan menjadikan kota tersebut sangat cocok sebagai kota hunian dan tempat peristirahatan.

Fungsi sebagai kota hunian ini membuat Malang tidak dirancang sebagai kota dagang dan kota industri. Malang dijadikan sebagai hunian bagi orang-orang Eropa pemilik perkebunan yang berada di wilayah sekeliling Kota Malang. Selain itu, Malang termasuk Batu juga menjadi tempat peristirahatan favorit bagi orang-orang Eropa yang tinggal di Surabaya.

Sebelum diresmikan sebagai kotapraja sendiri, Malang sebelumnya berada di wilayah Karesidenan Pasuruan. Kelahiran kota Malang pada tahun 1914 sendiri dianggap cukup prematur. Saat itu Malang baru saja berkembang sangat pesat sehingga belum memiliki kelengkapan seperti layaknya kota lain seperti dewan kota serta wali kota. Tahun 1819 merupakan saat peresmian kota Malang sebagai bagian karesidenan Pasuruan. Pada masa itu, Malang hanya dikenal sebagai tempat liburan yang ideal bagi masyarakat Eropa karena hawanya yang sejuk dan terletak di lokasi yang cukup tinggi.

Perkembangan yang sangat pesat pada Malang ini sendiri juga dialami hampir seluruh kota di Jawa. Ingleson (2015: 17) menjelaskan bahwa kota-kota besar dan kecil di Jawa tumbuh pesat setelah koloni terbuka untuk modal swasta sejak 1870-an. Wilayah urban yang paling berkembang pada masa itu adalah Surabaya yang merupakan salah satu pelabuhan utama di Hindia Belanda. Malang sendiri sebagai wilayah yang berada cukup dekat dengan Surabaya dan memiliki berbagai industri yang menunjang turut tumbuh dengan pesat karena hubungan dan akses yang sangat mudah dengan Surabaya.

Perkembangan pesat ini kemudian mendorong Malang yang sebelumnya hanya wilayah yang kecil menjadi naik statusnya. Posisi Malang sebagai kota distribusi menuju Surabaya dan wilayah lain untuk berbagai hasil produksi seperti gula, teh, dan kopi menjadikan perkembangan perekonomian kota ini meningkat pesat. Pada saat menjadi bagian dari Karesidenan Pasuruan, Kota Malang merupakan salah satu bagian dari Kabupaten Malang. Saat itu, 
Malang mempunyai delapan kawedanan atau distrik yang terdiri dari Karanglo, Pakis, Gondanglegi, Penanggungan, Sengoro, Antang (Ngantang), Turen dan kawedanan Kotta. Sebagai salah satu kawedanan, wilayah dari kota Malang sendiri membawahi 13 kampung. Seluruh kampung ini kemudian menjadi wilayah dari kota Malang yang kita kenal saat ini, yaitu Kidulpasar, Taloon (Talun), Kahooman (Kauman), Leddok, Padeyan, Klojen, Lor Alun, Gadang, Tameengoonhan (Temenggungan), Palleyan (Polean), Jodeepan (Jodipan), Kabalen dan Cooto lawas ( Kota lama).

Setelah melihat perkembangan Malang yang dianggap cukup cepat dan dinilai siap, Malang akhirnya dijadikan sebuah kotapraja sendiri. Pada awal pendiriannya,jabatan wali kota di Malang masih dirangkap oleh asisten residen Fl. Broekveldt yang kemudian digantikan oleh JJ. Coert dan akhirnya pada tahun 1919 Malang memiliki Mr. HI. Bussemarker sebagai wali kota terpilih.

Setelah Malang mendapat status sebagai kotapraja pada tahun 1914, hal pertama yang dilakukan oleh pemerintah kota adalah melakukan Rencana Perluasan Pembangunan Kota atau yang biasa disebut sebagai Bouwplan. Rencana pembangunan kota ini sendiri dibagi menjadi delapan bagian dan bersifat kronologis. Basundoro (2005: 276) menyebut bahwa perencanaan ini dimaksudkan agar proses pembangunan dan perluasan kota dapat disesuaikan dengan dana yang ada dan tidak dilakukan sekaligus.

Perancangan Malang sebagai kota hunian yang nyaman sendiri dilakukan oleh perancang kota, Ir. Herman Thomas Karsten. Masyarakat Eropa di Malang menghendaki agar kota ini dibuat semirip mungkin kota mereka di Eropa sehingga ditunjuk seorang perancang kota untuk mengembangkan Malang. Karsten membuat rencana pembangunan kota dalam beberapa tahap yang terencana terutama pada wilayah pemukiman Eropa dan pusat pemerintahan.

Selain membuat Bouwplan, Basundoro (2005: 276) juga menyoroti beberapa hal yang dilakukan untuk menjadikan Kota Malang sebagai kota yang yang teratur dan nyaman. Hal pertama adalah dibangunnya jaringan di dalam kota yang menjadikan Malang sebagai kota yang teratur dan nyaman. Kedua, kota dibangun untuk memiliki ruang terbuka yang cukup luas, baik berupa lapangan maupun taman yang bertujuan sebagai jantung kota dan mengendorkan syaraf warga kota.

\section{Industrialisasi Dan Tumbuhnya Ekonomi Malang}

Beberapa tanaman yang jadi dasar industrialisasi di wilayah Malang seperti Kopi dan Tebu sebenarnya lahir dari adanya Sistem Tanam Paksa pada masa sebelumnya. Sistem Tanam Paksa atau Cultuurstelsel sendiri sebenarnya bertujuan 
mengekstraksi surplus ekonomi secara maksimal dari tanah jajahan ke negeri Belanda. Sistem ini membuat setiap tahun rakyat wajib menyetor komoditi ekspor yang laku di pasar Eropa seperti gula dan kopi dalam jumlah yang telah ditentukan (Boediono, 2016: 49).

Sistem Tanam Paksa ini berlangsung mulai tahun 1830 dan berakhir pada 1870 sebelum akhirnya digantikan oleh Kebijakan Ekonomi Liberal. Kebijakan yang baru ini membuka lebar Hindia Belanda bagi usaha swasta dan secara prinsip tidak lagi memaksa rakyat dalam kegiatan ekonomi termasuk dalam penggunaan lahan dan penggunaan tenaga kerja. Walau begitu, dalam praktiknya masih terdapat berbagai perintah dan paksaan di tingkat petani, pekebun, dan masyarakat awam.

Boediono (2016: 52) menjelaskan bahwa pada tahun 1870 ini terdapat dua undang-undang penting yang mengubah perekonomian Hindia Belanda yaitu Undang-Undang Agraria dan UndangUndang Gula. Undang-Undang Agraria ini membolehkan pengusaha swasta untuk: (a). menyewa tanah sawah penduduk asli secara tahunan; dan (b). mendapatkan konsesi 75 tahun dari pemerintah untuk menggunakan tanah yang tidak dibudidayakan penduduk.

Undang-undang Gula sendiri menghapus sistem tanam paksa gula yang merupakan salah satu komoditas paling penting pada masa itu. Sekitar dua dasawarsa sejak undang-undang ini diterapkan, dampaknya di sektor perekonomian baru mulai terasa. Data Van Zanden \& Marks (2012: 172) menunjukkan peningkatan sangat luar biasa pada ekspor Indonesia terutama beberapa bahan. Gula mengalami peningkatan signifikan sebesar 266\% dari tahun 1874 ke 1914. Jika pada 1874 terdapat 50 Juta Gulden untuk gula yang diekspor, pada 1914 melonjak menjadi 183 Juta Gulden. Gula sendiri merupakan salah satu industri yang menopang berdirinya kota Malang masa-masa awal.

Handinoto dan Soehargo (1996: 10) menyadari bahwa usai diterapkannya Undang-undang Gula dan Undang-undang Agraria ini membuat Malang yang sebelumnya merupakan kota pedalaman dengan infrastruktur yang buruk jadi berkembang. Munculnya pemoda-pemodal swasta yang mendirikan perkebunan di wilayah Jawa. Letak geografis Malang yang dikelililingi oleh daerah perkebunan sangat menarik bagi pihak swasta.

Setelah tahun 1870, Malang sebagai salah satu wilayah pemerintahan yang paling dekat dengan daerah perkebunan mulai memiliki infrastruktur dan komunikasi yang memadai. Infrastruktur yang dibangun ini tidak hanya mencakup antar kota saja namun juga di dalam kota.

\section{Kejayaan Industri Gula Pada 1900-} 1930

Ham (2002: 63) menyebut bahwa gula dari Pulau Jawa pada masa pemerintah kolonial Hindia Belanda dapat diibaratkan 
sebagai gabus tempat Pulau Jawa mengapung. Hal ini muncul lantaran perekonomian pemerintah kolonial berpusat di Pulau Jawa karena sebelum terjadi penurunan pada tahun 1930, hampir seperempat penghasilan Pemerintah Hindia Belanda berasal dari gula. Walaupun gula mulai ramai menjadi komoditas utama bagi pemerintah hindia Belanda setelah diberlakukan Undang-undang Gula pada 1870, namun tanaman tebu sebagai bahan bakunya telah berusia sangat panjang.

Ham (2002: 64) menuturkan bahwa tebu sudah ada di Pulau Jawa sebelum Belanda datang dan diperkirakan dibawa oleh orang India atau Arab yang mengolahnya menjadi gula secara primitif. Sebuah catatan dari pengelana asal Amerika Serikat, Albert S. Bickmore (dalam Rush, 2013) pada tahun 1868 menuturkan mengenai perjalanannya ke perkebunan tebu di wilayah sekitar Surabaya. Tanaman tebu pada masa itu ditanam bergantian di lahan yang sama dengan tanaman lain.

Pengolahan tebu yang dilihat Bickmore sendiri berada di pabrik gula yang cukup besar. Selain menjadi gula, hasil olahan tebu tadi yang berupa air kemudian diproses dan difermentasikan dengan beras serta cairan manis dari getah pohon yang kemudian menjadi arak dan diekspor dalam jumlah besar ke daerah dingin seperti Swedia dan Norwegia. Pada masa antara 1830-1870 ketika diberlakukan Tanam Paksa, penanaman tebu yang sebelumnya tidak menjadi perhatian pemerintah kolonial Hindia Belanda mulai digalakkan. Pasca 1870 ketika penghapusan sistem Tanam Paksa, gula menduduki posisi yang semakin penting di Hindia Belanda dan tumbuh berbagai pabrik gula terutama di sekitar Pulau Jawa.

Pada masa 1900-an awal, pemerintah Hindia Belanda tengah getol mendorong tumbuhnya industri gula secara massal. Peraturan global pada saat itu juga menunjang terjadinya produksi gula ini secara besar-besaran. Salah satu daerah andalan mereka dalam membangun industri ini adalah di Jawa Timur. Hal itu lah yang menyebabkan mulai berdirinya dua pabrik gula di Malang dalam waktu yang cukup berdekatan. Pabrik Gula Kebon Agung muncul pada 1905 dan Pabrik Gula Krebet pada 1906 menjadikan Malang berkembang lebih pesat.

Ketersediaan bahan baku tebu di wilayah selatan dan timur Malang menjadikan wilayah tersebut sangat ideal untul melahirkan industri gula. Berdirinya dua pabrik ini juga menjadikan masyarakat semakin tertarik untuk bergeser menanam tebu karena tingginya kebutuhan bahan baku dari industri ini. Secara umum, industri gula di Jawa mengalami masa bulan madu pada sekitar dekade 1920-an. Pada masa itu, Pemerintah Hindia Belanda memiliki ratusan pabrik gula yang menjadi sektor andalan dan salah satu komoditi ekspor utama mereka. Walaupun gula 
dianggap sebagai komoditas ekspor utama pada 1920-an, namun pada masa sebelumnya industri gula di Jawa ini hampir berakhir bahkan sebelum menjadi raksasa. Van Zanden dan Marks (2012: 180) mencatat bahwa pada tahun 1884 sempat terjadi krisis gula di Jawa. Pada masa itu harga gula Jawa ditekan sangat rendah karena pemerintah Hindia Belanda mencoba menjauhkan hasil ekspor tersebut dari gula bit milik mereka sendiri, selain itu juga merebaknya hama baru yang mengakibatkan terjadinya beberapa kali gagal panen.

Lesunya penghasilan dari industri gula tersebut, membuat organisasi pemilik pabrik lokal di Jawa melakukan penelitian untuk mengatasi hama tersebut. Terdapat tiga proefstations yang didirikan masingmasing di Jawa Barat, Jawa Tengah, dan Jawa Timur. Tindakan ini ternyata berbuah manis dengan meningkat pesatnya nilai ekspor gula sejak 1890 yang hanya 52 juta Gulden, menjadi 74 juta Gulden pada 1900 dan meningkat hampir dua kali lipat pada 1910 menjadi 140 juta Gulden.

Saking pentingnya peran gula pada ekonomi Hindia Belanda, Ham (2005: 65) menyebut gula merupakan faktor penggerak utama kapitalisme di Jawa. Bahkan di Mangkunegaran, Kasunanan Solo, dan Kasultanan Yogyakarta mengganti sistem pembayaran abdi dalem dan priyayi yang sebelumnya dengan tanah dan menjadikan tanah tersebut menjadi pabrik gula yang pendapatannya kemudian digunakan untuk menggaji mereka. Politik Etis Hindia Belanda yang secara resmi dihentikan pada tahun 1930-an membuat industri gula yang sebelumnya menjadi primadona menjadi korban. Van Zanden dan Marks (2012: 203) menjelaskan bahwa sejak awal, industri gula memang berada di posisi yang lemah dan penuh dengan persaingan dari luar. Industri gula lokal harus berhadapan tidak hanya dengan industri gula tebu dari Karibia dan India saja melainkan juga dengan gula bit yang diproduksi oleh Eropa sendiri.

Menguatnya industri ini masa 1900an sendiri didorong oleh penandatangan Konvensi Gula Brussel pada tahun 1902 yang membuat gula diperdagangkan secara bebas dan mendorong pembaruan pertumbuhan industri gula di Indonesia. Konvensi ini juga menyebabkan Hindia Belanda terutama Jawa menjadi memiliki banyak pabrik gula untuk menyokong industri ini. Sayangnya, pada 1931 ketika harga-harga mulai jatuh dan peningkatan proteksi internasional memaksa produksi berlebih dari komoditas ini.

Selain itu, Belanda sebagai salah satu tujuan utama pengiriman gula Jawa juga menaikkan bea impor sehingga akhirnya industri gula lokal semakin terancam dan memaksa mengurangi produksinya. Geertz (2016: 91) menyatakan bahwa tingginya hasil tebu di Jawa juga tak lepas karena penduduk di situ sudah tak memiliki pilihan. Karena distribusi sawah 
dan penduduk yang tidak merata, mereka terpaksa untuk mengusahakan sawah secara lebih giat dan menggarap seluruh sumber daya secara lebih seksama untuk menanggulangi kenaikan jumlah mereka. Hal ini juga tak lepas dari tiadanya sektor industri yang mampu menampung mereka jika para berpindah lapangan pekerjaan.

Walau begitu, gula memang menyediakan tak hanya pendapatan yang luar biasa besar saja namun juga lapangan pekerjaan yang cukup melimpah. Geertz (2016: 109) menyebut bahwa pada 1930 perusahaan-perusahaa gula mempekerjakan lebih dari 800.000 pada hari-hari tertentu di sepanjang tahun dengan kurang lebih 4.0005.000 orang pada 180 pabrik yang ada. Kemegahan industri gula ini akhirnya harus kandas juga pada 1931 dan memaksa berbagai pabrik gula serta petani dan buruh yang ada menyesuaikan diri dan mengurangi produksinya. Malang yang memiliki dua pabrik gula juga turut terimbas masalah ini.

Dua pabrik gula di Malang memiliki sejarah pendirian yang cukup berbeda walaupun berada di kisaran tahun yang sama. Pabrik Gula Kebon Agung didirikan pada tahun 1905 oleh seorang pedagang Tionghoa asal Surabaya, Tan Tjwan Boe. Perusahaan ini berada di jalur perlintasa antara Malang-Blitar dan masih berstatus perusahaan perorangan hingga tahun 1917. Setelah mulai dibangun dan didirikan pada 1905, PG Kebon Agung baru benar-benar beroperasi pada tahun 1908. Pabrik ini mampu memproduksi hingga 8000 pikul atau 5000 kuintal tebu perharinya. Pada tahun 1913, kapasitas produksinya meningkat menjadi 10.000 pikul tebu perharinya. Pada 1917, status Kebon Agung yang semula perorangan diubah menjadi perseroan dengan nama NV Suikerfabriek Keboen Agoeng, Tan Tjwan Bie sendiri menjadi direkturnya.

Pada masa setelahnya, PG Kebon Agung mencoba mencari tambahan dana dengan menghipotikkan pabriknya kepada De Javasche Bank. Sayangnya, depresi ekonomi yang terjadi dan pembatasan ekspor gula membuat PG Kebon Agung tak mampu membayar tagihannya sehingga pada 1935 seluruh saham perseroan akhirnya dimiliki sepenuhnya oleh De Javasche Bank.

Berbeda dengan Pabrik Gula Kebon Agung yang dimiliki oleh pihak swasta, Pabrik Gula Krebet Baru pada awalnya didirikan oleh pemerintah Hindia Belanda. Seiring berjalannya waktu, pabrik ini dibeli oleh sang raja gula asal Semarang, Oei Tiong Ham. Pabrik gula ini selanjutnya berada di bawah kepemilikan Oei Tiong Ham Concern (OTHC).

Pabrik Gula Krebet Baru sendiri tetap berada di bawah kepemilikian OTHC hingga masa kemerdekaan. Walau sempat rusak parah, pabrik gula ini dibangun kembali pada tahun 1947 dan kembali berproduksi. Pada tahun 1961, akibat 
adanya dugaan pelanggaran dalam peraturan mengenai valuta asing, seluruh aset OTHC termasuk PG Krebet Baru disita oleh negara dan dikelola oleh PT Rajawali Nusindo yang berstatus BUMN.

\section{Berjayanya Industri Tembakau Pada 1930}

Menurunnya industri gula di Hindia Belanda tak serta merta membuat Malang yang memiliki PG Krebet dan Kebon Agung terpukul secara keras. Masih ada satu industri lagi yang mulai berkembang ketika bonanza industri gula mulai berakhir, dan itu adalah industri tembakau atau rokok. Selain gula, industri penting lain yang mendorong terbentuknya kotapraja Malang adalah tembakau atau rokok.

Industri ini sendiri hingga kini masih tetap ramai dan menyerap banyak tenaga kerja di Malang. Pada masa lalu, perusahaan rokok yang berada di Malang dan memiliki pengaruh cukup besar adalah Bentoel yang masih bertahan hingga kini serta Faroka perusahaan rokok asal Belgia. Dukut Imam Widodo (2006) menyebut bahwa Faroka didirikan di Malang pada tanggal 13 Juni 1931. Lokasi dari pabrik ini sendiri adalah di Industrieweg atau jalan Peltu Sujono pada saat ini. Produk dari Faroka sendiri pertama meluncur pada bulan April 1931.

Sebagai salah satu produsen rokok yang cukup ternama pada masa itu, pabrik Faroka memiliki teknologi yang cukup maju. Berbagai mesin sudah digunakan untuk memproduksi rokok di pabrik ini. Selain itu Faroka juga memiliki gudang yang sangat besar dan dibangun untuk mempertahankan suhu tembakau di dalamnya agar tetap dingin dan kualitasnya terjaga. Faroka sendiri disebut mampu memproduksi hingga 60.000 batang rokok setiap harinya. Rokok yang diproduksi di pabrik ini adalah rokok putih yang pada saat itu belum umum beredar dan dihisap masyarakat lokal.

Pabrik dari Faroka ini sendiri adalah pabrik rokok putih terbesar di Indonesia dan Asia pada masa itu sehingga mampu menyerap cukup banyak tenaga kerja. Dekade 1930-an sendiri memang merupakan masa lahirnya industri rokok di Malang. Selain Faroka, salah satu merek lokal yang sampai saat ini masih ada yaitu Bentoel juga berdiri pada dekade tersebut. Bentoel sendiri atau pada masa itu masih bernama Strootjes Fabriek Ong Hok Liong dan lahir lebih dahulu pada tahun 1930.

Walau begitu, ketika lahir, Bentoel masih merupakan perusahaan yang kecil dibanding NV Faroka dan terletak di jalan petjinan ketjil. Pabrik Strootjes Fabriek Ong Hok Liong ini didirikan oleh Ong Hok Liong dengan memproduksi rokoknya secara tradisional. Nama dari rokok ini sendiri sempat berganti beberapa kali mulai dari Hien An Konsie, Burung, Gendang, Kelabang, Lampu, Turki, Jeruk Manis, dan akhirnya baru berhasil ketika diberi nama Bentoel. Pada masa sebelum kemerdekaan sendiri, 
Bentoel tidak memainkan peran yang cukup besar dalam industri rokok di Malang. Keberhasilan Bentoel baru terjadi pada 1950-an dan bahkan pada 1960-an mereka menjadi perusahaan pertama di Indonesia yang memproduksi rokok kretek filter dan membungkus kotak rokoknya dengan plastik. Dalam Imam Widodo (2006: 214) mendata bahwa pada masa itu, terdapat 18 pabrik rokok di wilayah Malang, yaitu:

1. NV Faroka, jalan Peltu Sujono

2. Bentoel, jalan Wiromargo

3. PT Grendel, jalan Sepur 13

4. PT Banyubiru, jalan Talun Lor

5. PT Atoomcy, jalan Industri Barat

6. Podo Rukun, jalan Tanjung 81

7. Lima Jari, jalan Tanjung 115

8. CV Sam Sam Sam, Jalan Belakang Pasar II/4

9. Sempati, jalan Sukun 63

10. PT Tugu Mas, Temenggungan Wetan 8-12

11. PT Gita Widjaja, Jalan Mergosono 82

12. Damai, Rampal Dalam 11a

13. NV The Djie Siang, Jalan Pattimura 52

14. PT Thong Gwan, Jalan Glintung 36

15. PR Rambon, Jalan Belakang Loji

16. Kian Gie, Jalan Mergosono 28

17. PT Baut, Jalan Blimbing 10

18. Betel, Jalan Tenaga 3 Jumlah pabrik rokok yang cukup banyak di wilayah Malang ini menunjukkan bahwa mereka memainkan peran yang cukup besar dalam perkembangan kota. Beberapa pabrik rokok ini masih bertahan saat ini seperti Grendel dan Banyubiru. Walau mungkin pada dekade 1930-an perusahaan rokok itu belum besar, namun keberadaan NV Faroka yang merupakan salah satu pabrik rokok terbesar membuat industri tembakau ini memainkan peran yang cukup besar dalam perkembangan Malang pada awal abad ke-20.

Berbeda dengan gula, rokok sendiri lebih banyak diproduksi untuk pasar lokal dan tidak diekspor. Hal itulah yang menyebabkan industri rokok di Malang mulai muncul pada 1930 ketika industri gula sudah meredup akibat pembatasan produksi dan ekspor gula yang terjadi di masa itu.

Pasar rokok yang begitu besar di Hindia Belanda juga mendorong masuknya perusahaan internasional seperti NV Faroka yang dimiliki NV Tobacofina asal Belgia di Malang serta British American Tobacco (BAT) yang mendirikan pabrik di Cirebon. Kelak, BAT mengakuisisi pula salah satu perusahaan rokok asal Malang yaitu Bentoel.

\section{Revolusi Transportasi Di Malang}

Industrialisasi di Jawa termasuk Malang tidak bisa dilepaskan sebagai penyebab berkembangnya transportasi di pulau tersebut. Pada beberapa pabrik terutama pabrik gula, salah satu sarana utama untuk mengangkut bahan baku dan hasil produksi adalah menggunakan jalur kereta api. Pabrik gula di Jawa selalu identik dengan jalur lori yang sayangnya saat ini mulai ditinggalkan. Jalur kereta di Hindia 
Belanda sendiri pertama kali dibangun pada tahun 1867 untuk menghubungkan Semarang sengan kota-kota kerajaan Yogyakarta dan Surakarta (Van Zanden dan Marks, 2012: 184). Pada awalnya, pemerintah Hindia Belanda menyerahkan perkembangan dari transportasi ini melalui inisiatfi pihak swasta. Namun, sejak tahun 1880-an hingga selanjutnya, pemerintah mulai lebih aktif dalam menghubungkan beberapa jalur yang ada dan memperluas jaringan hingga mencakup semua daerah penting Jawa. Pembangunan jaringan kereta api ini sendiri membuat biaya transportasi menjadi jauh lebih rendah dan efektif.

Basundoro (2005: 242) menjelaskan bahwa Jaringan kerta api antarkota ini mulai masuk ke Malang pada tahun 1879. Jurusan yang tersedia pada masa itu adalah jurusan Malang-Surabaya yang selanjutnya pada 1914 dilayani oleh empat buah kereta api yang masing-masing terdapat dua kereta yang berangkat dari dan ke Malang.

Jalan kereta api antar kota ke Malang baik dari Surabaya dan Pasuruan ini sendiri disebut Handinoto dan Soehargo (1996: 10) mulai diresmikan pada $16 \mathrm{Mei}$ 1878. Selain itu, pada masa yang sama ini juga dibangun jalan raya yang menghubungkan Malang dengan Blitar dan Kediri. Selain jalur kereta untuk transportasi antarkota, jalur tram dan lori juga dibangun melintang mulai dari ujung utara di Lawang hingga ke daerah selatan seperti Gondanglegi dan Dampit, serta sebuah jalur yang mengarah ke Tumpang. Jaringan ini sendiri dioperasikan oleh NV Malang Stoomtrammaatschappij (Maskapai Trem Uap Malang) mulai 14 november 1897.

Stasiun tram di Kota Malang ini berada di wilayah sekitar Jagalan, dekat dengan kantor NV Malang Stoomtrammaatschappij (MSM) yang ada di wilayah jalan Halmahera. Bekas jalur ini bahkan saat ini masih dapat dilihat sisanya di wilayah Jagalan. Jalur tram ini bahkan dibangun di jalan-jalan protokol kota Malang dan mempermudah transportasi ke berbagai wilayah lain di sekitar Malang Raya.

Jalur tram pertama yang dibuka untuk menghubungkan wilayah Malang adalah dari Jagalan menuju Stasiun Bululawang. Selanjutnya mulai dibuka ke jalur-jalur lain menuju stasiun Gondanglegi, stasiun Talok, stasiun Dampit, stasiun Kepanjen, stasiun Tumpang, stasiun Singosari, stasiun Blimbing, dan stasiun Sedayu. Di dalam kota sendiri, jalur tram berada di sepanjang jalan protokol Malang dari daerah Belimbing hingga mengarah langsung ke selatan menuju ke stasiun tram Jagalan.

Selain digunakan untuk sarana angkutan massal masyarakat, jalur tram atau lori ini juga dimanfaatkan oleh dimanfaatkan oleh PG Kebon Agung maupun PG Krebet untuk mengirim tebu dari berbagai wilayah Malang ke pabrik 
mereka. Hingga awal tahun 90-an, masih banyak lori yang melintas di jalur-jalur tram tersebut terutama yang mengarah ke selatan untuk membawa tebu.

Selain pembangunan jalur tram, Basundoro (2009: 242) menuturkan bahwa jaringan transportasi di Kota Malang juga mulai diperbaiki pada tahun 1920 dengan cara mengaspal semua jaringan jalan di kota. Pola jaringan jalan di Malang sendiri cukup teratur dan terpusat di wilayah alunalun dan menyebar dan berjaring hingga wilayah lain di dalam Kota Malang.

Jaringan jalan di Kota Malang sendiri dibuat secara terpadu dengan memperhatikan fasilitas kota yang lain serta terintegrasi dengan rencana pengembangan Kota Malang. Pengembangan jaringan jalan yang terpadu di Malang ini dibuat Thomas Karsten dengan membedakan kelas jalan antara jalan-jalan utama dan jalan-jalan pembagi yang dilalui oleh lalu lintas kendaraan. Jalan-jalan utama dibuat dengan berhubungan satu sama lain. Karsten membuat jalan utama sebagai penentu apakah infrastruktur lalu lintas dapat berjalan dengan lancar dan aman atau tidak akrena kemanan dan kelancarannya menentukan organisme kota berjalan dengan baik.

\section{Masalah Sosial Dari Industrialisasi Kota Malang}

Berubahnya status Malang menjadi kotapraja dengan segala gula-gula pembangunannya terutama dalam hal ekonomi juga mendatangkan masalahnya sendiri. Reza Hudiyanto (dalam Margana dan Nursam, 2010) menyebut bahwa perkembangan kota ini tidak hanya mendorong migrasi besar-besaran masyarakat Eropa namun juga bumiputra. Perubahan aktivitas hidup dari agraris yang tidak menuntut banyak keahlian menjadi aktivitas jasa yang menuntut keahlian telah menyebabkan sejumlah masyarakat tersingkir.

Setidaknya terdapat tiga kelompok masyarakat yang menjadi korban dari industrialisasi dan modernisasi Malang ini. Ketiga kelompok tersebut adalah gelandangan, pengemis, dan prostitut. Hudiyanto (dalam Margana dan Nursam, 2010: 134) menyebut bahwa ketiga kelompok ini paling sering beraktivitas di jalanan dan memunculkan fenomena yang disebut kebudayaan miskin.

Gelandangan sendiri disebut telah berada di Malang sejak 1847 dan biasa disebut sebagai vagabond atau landloopers. Kelompok ini sendiri biasa memanfaatkan los-los pasar, stasiun, dan makam sebagai tempat tinggal mereka. Disebut bahwa gelandangan ini terdiri dari beberapa usia baik muda ataupun tua. Dari pendataan yang dilakukan terhadap anak-anak gelandangan pada masa itu, diketahui bahwa mereka berasal dari wilayah lain seperti Mojokerto dan Sidoarjo. Walau diberi kesempatan untuk bekerja, anak- 
anak ini tidak mau melakukannya dan kembali meminta-minta seperti biasa.

Kelompok kedua yang muncul adalah pengemis. Mengenai pengemis di Kota Malang ini, catatan pertama diketahui memiliki tahun 1917 dan tidak disertai jumlah pasti walau disebut bahwa terdapat cukup banyak pengemis. Setiap tahun jumlah pengemis di wilayah Kotapraja Malang sendiri disebut terus bertambah. Beberapa pengemis yang pernah didata disebut berasal dari Kudus, Blitar, dan Kesamben. Bertambahnya jumlah pengemis ini membuat polisi mengalami dilema.

Perbedaan dari gelandangan dan pengemis ini adalah tidak semua gelandangan mau meminta-minta seperti pengemis. Walau begitu keduanya biasanya sama-sama tinggal di jalanan atau tempattempat umum lainnya, tidak memiliki pekerjaan tetap, dan merupakan ancaman bagi keamanan dan ketertiban kota pada masa itu.

Masalah sosial ketiga yang muncul adalah terjadinya prostitusi. Hudiyanto (dalam Margana dan Nursam, 2010: 136) menyebut bahwa prostitusi ini kemungkinan telah ada di kota Malang sejak akhir abad ke-19 walaupun baru disebut secara konkret pada 1915. Munculnya prostitusi ini sendiri disebut karena pertumbuhan populasi kota yang dipicu oleh peningkatan ekspor produk-produk primer Belanda seperti gula. Meningkatnya penduduk ini juga meningkatkan kebutuhan hiburan bagi masyarakatnya termasuk bagi para jejaka untuk menyalurkan nafsunya.

Salah satu kampung di Malang yang identik dengan tempat prostitusi adalah Kebalen. Pada akhir abad ke-19, Kebalen merupakan salah satu gudang palawija dan tempat aktivitas para saudagar besar yang terdiri dari berbagai toko. Pusat prostitusi ini sendiri berada pada wilayah kampung di sekitaran Kebalen dan tidak muncul secara terang-terangan di wisma-wisma namun berada di warung-warung kopi.

Pelaku dari prostitusi ini kebanyakan merupakan migran dari Batu dan Blitar. Walau Kebalen disebut merupakan pusat prostitusi di Malang, namun pada masa itu di segala penjuru kota praktik ini terjadi terutama di wilayah stasiun dan warung. Hotel dan restoran juga menjadi sarang dari praktik prostitusi ini sehingga akhirnya muncul peraturan jam buka restoran dan tempat hiburan lain.

\section{Penutup}

Diterapkannya Undang-undang Gula dan Undang-undang Agraria pada tahun 1870 telah mendorong wilayah Malang semakin berkembang dan menjadi Kotapraja pada tahun 1914. Perubahan status ini disebabkan karena Malang sebagai wilayah perkotaan yang berada paling dekat dengan sejumlah perkebunan.

Kota Malang sendiri kemudian dirancang sebagai kota peristirahatan bagi orang Eropa yang bekerja dan memiliki 
perkebunan di sekitarnya. Pada awal abad ke-20, perkembangan ini juga ditandai dengan berdirinya industri gula dan rokok di wilayah Malang yang membuat perkembangan kota ini semakin pesat.

Dua pabrik gula yaitu Kebon Agung dan Krebet Baru mulai berdiri di Malang pada kisaran abad ke-20. Kedua pabrik gula ini membuat perkembangan Malang semakin pesat dengan meningkatnya ekonomi masyarakat serta dibangunnya jalur lori yang juga digunakan oleh kedua pabrik gula tersebut.

Setelah industri gula menemui senjakalanya pada kisaran tahun 1930, industri rokok kemudian menjadi penopang perkembangan Malang. Masuknya NV Faroka, perusahaan rokok asal Belgia di Malang dengan pabrik yang disebut terbesar di Asia menyebabkan banyak tenaga kerja yang terserap dan perekonomian Malang tetap melaju. Selanjutnya pabrik rokok yang semula berstatus rumahan seperti Bentoel juga berkembang dan selanjutnya membantu menopang perekonomian.

Pesatnya perkembangan ini menyebabkan Malang memiliki transportasi yang cukup memadai baik di dalam kota maupun antar kota. Selain itu jalanan yang cukup memadai juga dibangun dalam kota Malang dan juga kepada kota tetangga seperti Surabaya, Blitar, Pasuruan, dan lain sebagainya.

Kemajuan yang pesat dari kota Malang disebabkan industrialisasi ini juga menyebabkan munculnya masalah sosial pada masyarakat. Sebagian masyarakat yang ingin mencoba mencari peruntungan walaupun tak memiliki kemampuan terpaksa menjadi gelandangan atau pengemis. Selain itu, berkembangnya perkotaan ini juga memunculkan masalah berupa prostitusi yang berkembang di kota Malang.

\section{Daftar Pustaka}

Basundoro, Purnawan. 2009. Dua Kota Tiga Zaman; Surabaya dan Malang sejak Kolonial sampai Kemerdekaan.Yogyakarta: Penerbit Ombak.

Boediono. 2016. Ekonomi Indonesia dalam Lintasan Sejarah. Bandung: Mizan.

Geertz, Clifford. 2016. Involusi Pertanian: Proses Perubahan ekologi di Indonesia. Jakarta: Komunitas Bambu.

Ham, Ong Hok. 2002. Dari Soal Priyayi sampai Nyi Blorong: Refleksi Historis Nusantara. Jakarta: Kompas.

Handinoto \& Soehargo, Paulus H. 1996. Perkembangan Kota dan Arsitektur Kolonial Belanda di Malang. Yogyakarta: Andi.

Ingleson, John. 2015. Buruh, Serikat, dan Politik: Indonesia pada 1920an1930an. Jakarta: Marjin Kiri.

Margana, Sri \& Nursam, M. 2010. Kota-kota di Jawa; Identitas, Gaya Hidup dan Permasalahan Sosial. Yogyakarta: Penerbit Ombak.

Van Zanden, Jan Luiten \& Marks, Daan. 2012. Ekonomi Indonesia 1800-2010; Antara Drama dan Keajaiban Pertumbuhan. Jakarta: Kompas.

Widodo, Dukut Imam, dkk. 2006. Malang Tempo Doeloe. Malang: Bayu Media Publishing. 